\title{
Performance of Lactating Dairy Cows Fed Silage and Grain from a Maize Hybrid with the cry1F Trait Versus its Nonbiotech Counterpart
}

\author{
M. Faust, ${ }^{\star 1}$ B. Smith, $\uparrow$ D. Rice,$\dagger^{2}$ F. Owens, $\dagger$ M. Hinds, $\uparrow$ G. Dana, $\uparrow$ and P. Hunst $\ddagger$ \\ *Department of Animal Science, 123 Kildee Hall, lowa State University, Ames 50010 \\ †Pioneer Hi-Bred, a DuPont business, 7300 NW 62nd Ave., Johnston, IA 50131 \\ ‡Dow AgroSciences LLC, 9330 Zionsville Road, Indianapolis, IN 46268
}

\begin{abstract}
Effects of feeding grain and maize silage from a non$\mathrm{Bt}$ maize and a variety of $\mathrm{Bt}$ maize that contains cry $1 \mathrm{~F}$ (event TC1507, event DAS-Ø15Ø7-1), a gene that provides maize with insect resistance, on the health and performance of dairy cows were evaluated. In a crossover trial, 20 lactating Holstein cows were assigned to each of 2 dietary treatment groups and fed diets containing whole-plant maize silage plus maize grain from TC1507 or its near-isoline counterpart (control). Each period of the crossover trial lasted $28 \mathrm{~d}$ and was preceded by a $7-d$ adjustment period. To minimize variability due to stage of lactation, 2 blocks of 10 cows at 90 to $130 \mathrm{~d}$ of lactation at the start of the trial were used. Within each dietary treatment, 10 cows were from each of 2 genetic selection lines (high and average fat plus protein predicted transmitting ability). Diets were formulated to be isocaloric and isonitrogenous. Dry matter intake and daily production of milk, fat, protein, lactose, nonfat solids, and total solids did not differ between cows fed the TC1507 diet and cows fed the control diet. Furthermore, milk from cows in different dietary treatment groups did not differ in milk urea nitrogen concentration or somatic cell count. For milk fat percentage, a significant dietary treatment by genetic group interaction was detected although overall yield of milk and solids-corrected milk did not differ with diet. Physical measures of cow health including body weight, body condition score, temperature, pulse, and respiration rate were collected weekly; dietary treatment group means for these measures were not different. Blood chemistry and hematological analyses were conducted using blood samples collected from cows before the start of the trial and at the end of each period. Overall, the TC1507 and control groups did not differ
\end{abstract}

\footnotetext{
Received June 25, 2007.

Accepted September 7, 2007.

${ }^{1}$ Current address: ABS Global, Inc., 1525 River Road, Deforest, WI 53532.

${ }^{2}$ Corresponding author: Dave.Rice@pioneer.com
}

in any of these indices of health status. Further, hematological profiles for cows in the dietary treatment groups were not different. In summary, no differences were detected in milk production, milk composition, or cow health as indicated by physical measures, blood chemistry, and hematological analyses between dairy cows fed diets containing maize grain plus whole-plant maize silage from TC1507 and dairy cows fed grain plus silage from its near-isoline counterpart.

Key words: $c r y 1 \mathrm{~F}$ gene, maize grain, maize silage, dairy cow

\section{INTRODUCTION}

Bacillus thuringiensis (Bt) is a common soil bacterium that produces proteins that are toxic to certain Lepidopteran pests. A new generation biotech maize (Zea mays L.) hybrid containing the cry $1 \mathrm{~F}$ gene (event TC1507) from Bacillus thuringiensis var. aizawai and the phosphinothricin acetyltransferase (pat) gene from Streptomyces viridochromogenes has been developed. The cry $1 \mathrm{~F}$ gene encodes the Cry $1 \mathrm{~F}$ protein that is insecticidal toward several lepidopteran pests of maize, including European corn borer, southwestern corn borer, fall armyworm, black cutworm, corn earworm, and western bean cutworm. The expressed PAT protein confers in planta tolerance to herbicides that contain the active ingredient glufosinate-ammonium (e.g., Liberty, Bayer Crop Science, Research Triangle Park, NC). This trait was developed through collaboration between Pioneer Hi-Bred International Inc. (Johnston, IA) and Dow AgroSciences LLC (Indianapolis, IN).

Maize serves as the major source of both energy and forage in diets for dairy cows in the United States. The use of biotech maize hybrids enhances yield under conditions of insecticidal pressure in the midwestern United States. Previous research by Faust and Miller (1997) and Folmer et al. (2002) demonstrated similar performance of dairy cows fed diets containing transgenic maize expressing the Cry1Ab protein from Bt events compared with diets containing their nontransgenic counterparts. 
The purpose of this study was to investigate dairy cow performance (milk and component yields) and health status of cows when fed a TMR containing silage plus grain produced from maize plants containing the cry $1 \mathrm{~F}$ gene (TC1507) vs. maize silage plus grain from plants of a similar genetic background, but not containing the cry $1 \mathrm{~F}$ gene.

\section{MATERIALS AND METHODS}

\section{Maize Grain and Silage Sources}

Pioneer Hi-Bred, a DuPont business (Johnston, IA) supplied maize grain and silage used in this study. Grain came from 2 isolated fields (separated by $201 \mathrm{~m}$ ) in Richland, Iowa; forage was produced from the same 2 hybrids as the grain in 2 isolated fields near Polk City, Iowa. The TC1507 maize grain and forage came from plants that received 2 sequential applications of glufosinate-ammonium herbicide (Liberty, Bayer Crop Science, Research Triangle Park, NC). The respective maize forages were custom harvested, delivered to the Iowa State University Dairy (Ankeny, IA), and ensiled in separate Ag Bags (Miller-St. Nazianz, St. Nazianz, WI) awaiting the start of the lactation study. Forages were harvested on September 27, 2001, with all equipment being cleaned between hybrids to prevent crosscontamination. Length of cut of forage was within the recommend range of 10 to $19 \mathrm{~mm}$ (Mueller et al., 1987; Roth and Heinrichs, 2001), with kernels being processed. Samples of harvested forage were submitted to Dairyland Labs (Arcadia, WI) for particle size analysis (ASAE, 2001) and analysis by wet chemistry methods for the following nutrients: moisture (AOAC, 1995), CP (AOAC, 1995), crude fat (AOAC, 1995), ADF, NDF, and lignin (Goering and Van Soest, 1970), ash (AOAC, 1995), calcium, phosphorus, magnesium, potassium (AOAC, 1995), and starch (determined with a YSI 2700 Select Biochemistry Analyzer; Application Note 322, YSI Incorporated, Yellow Springs, $\mathrm{OH}$ ).

\section{Diet Components, Preparation, Administration, and Sampling}

Two separate diets were prepared (Table 1) using whole-plant maize silage plus maize grain from either TC1507 or its near-isoline counterpart (Pioneer hybrid 33P66; control). Diets were formulated to meet or exceed all nutrient requirements for the lactating dairy cow (NRC, 2001). Soybean meal and whole cottonseed used in this trial were obtained from plants that were not transgenic. Maize grains and silages were analyzed for the presence of Cry $1 \mathrm{~F}$ protein using a specific ELISA to ensure that identity preservation was maintained throughout the study (Pioneer Hi-Bred). Grains were
Table 1. Ingredient composition of diets formulated with whole-plant maize silage plus maize grain from TC1507 or control plants ${ }^{1}$

\begin{tabular}{|c|c|c|}
\hline \multirow[b]{2}{*}{ Ingredient, $\mathrm{g} / \mathrm{kg}$ of diet DM } & \multicolumn{2}{|c|}{ Diet } \\
\hline & TC1507 & Control \\
\hline Maize silage & 302.0 & 299.0 \\
\hline Concentrate $\operatorname{mix}^{2}$ & 385.0 & 382.0 \\
\hline Soybean meal & 43.0 & 52.0 \\
\hline Whole cottonseed & 90.0 & 89.0 \\
\hline Alfalfa hay & 174.0 & 173.0 \\
\hline Dairy Supreme premix ${ }^{3}$ & 6.0 & 6.0 \\
\hline
\end{tabular}

${ }^{1} \mathrm{TC} 1507$ = maize plants containing the cry $1 \mathrm{~F}$ gene; Control = maize plants isogenic to TC1507 but not containing the cry $1 \mathrm{~F}$ gene.

${ }^{2}$ Concentrate mix contained percentage as-fed: ground maize, 70.2; Zinpro 4-Plex (Zinpro Corporation, Eden Prairie, MN), 0.068; fish meal, 2.7; animal fat, 1.4; soybean hulls, 4.5; sodium bicarbonate, 1.1; salt, 0.906; magnesium oxide, 0.226; limestone, 2.7; selenium, 0.226; urea, 1.1; vitamin E, 0.091; and AminoPlus (Ag Processing Inc., Omaha, NE), 14.7.

${ }^{3}$ Dairy Supreme premix (Land O'Lakes, St. Paul, MN): calcium (minimum 146,000 mg/kg); phosphorus (minimum 110,000 mg/kg); magnesium (minimum 60,000 mg/kg); potassium (minimum 30,000 $\mathrm{mg} / \mathrm{kg}$ ); sulfur (minimum $40,000 \mathrm{mg} / \mathrm{kg}$ ); zinc (minimum $6,440 \mathrm{mg} /$ $\mathrm{kg}$ ); manganese (minimum 4,315 mg/kg); iron (minimum 1,160 mg/ $\mathrm{kg}$ ); copper (minimum $1178 \mathrm{mg} / \mathrm{kg}$ ); iodine (minimum $99 \mathrm{mg} / \mathrm{kg}$ ); cobalt $(30 \mathrm{mg} / \mathrm{kg})$; selenium $(35.0 \mathrm{mg} / \mathrm{kg}$ ) vitamin A (minimum 660,000 IU/kg); vitamin D3 (minimum 132,000 IU/kg); and vitamin $\mathrm{E}$ (minimum $2640 \mathrm{IU} / \mathrm{kg}$ ).

sampled before the start of the trial and submitted for wet chemistry analysis (Dairyland Labs) for the previously listed nutrients with the exceptions of lignin, starch, and ash. Silages were sampled before the start of the trial and submitted (Dairyland Labs) for wet chemistry analysis for the previously listed nutrients, protein solubility (Krishnamoorthy et al., 1982), acid detergent insoluble $\mathrm{CP}$ determined by analyzing $\mathrm{ADF}$ residues for nitrogen (AOAC, 1995), $\mathrm{pH}$ (Eaton et al., 1995; method 4500-H+), and fermentation products by HPLC (Siegfried et al., 1984, with modification). Samples of grains and silages were also submitted for mycotoxin analysis (North Dakota State University Veterinary Diagnostic Laboratory, Fargo). Fusarium mycotoxins in grains and silages (nivalenol, deoxynivalenol, 3-acetyldeoxynivalenol, 15-acetyldeoxynivalenol, fusarenon X, diacetoxyscirpenol, scirpentriol, 15-acetoxyscirpentriol, T-2 toxin, iso-T-2 toxin, acetyl-T-2 toxin, T-2 triol, t-2 tetraol, HT-2 toxin, neosolaniol, zearalenol, and zearalenone) were analyzed as trimethylsilyl ester derivatives of tricothecenes and estrogens by GC-MS (Shimadzu QP5050, Tokyo, Japan; Raymond et al., 2003); aflatoxins were derivatized with trifluoroacetic acid, and fumonisins were derivatized with $o$-phthaldialdehyde and analyzed in grain samples by HPLC (Luna C18, Phenomenex, Torrance, CA, and Discovery C18, Supelco, Bellefonte, PA, respectively).

Diets were formulated based on the analyses of respective silages and grains and average milk production 
of groups. Fresh feed was prepared daily and cows were fed diets as a TMR twice per day at 0730 and $1630 \mathrm{~h}$. Cows were fed an excess of feed daily (8 to 10\%) to ensure that feed was available at all times; refusals were collected, sampled, and discarded every third day. Duplicate weekly samples of silages, grains, and diets were composited by sample type to form representative samples for each feeding period. Pooled samples of refusals were collected weekly throughout the experiment for each diet and composited for analysis to determine whether any preferential sorting of feed was evident. All samples were analyzed (Dairyland Labs) for moisture, $\mathrm{CP}$, crude fat, ADF, NDF, calcium, phosphorus, magnesium, and potassium by wet chemistry methods described previously.

\section{Dairy Cow Lactation Period}

Twenty Holstein cows from a dairy herd composed of 2 genetic groups were used in this trial using a crossover design. The genetic groups consisted of cows with either high or average genetic merit for PTA for milk fat and protein yield. Based on the variance observed in previous trials, the number of animal replicates per treatment, when fed individually, was determined to be adequate to detect at $P<0.05$, a 5 to $10 \%$ difference between treatment means $80 \%$ of the time. This sensitivity is comparable to current guidelines published by the International Life Sciences Institute (2003). The trial consisted of two 28-d feeding periods replicated in 2 blocks. Each period was preceded by a 7-d acclimation period (pretrial and transition). Cows received the alternate diet during the second period. Two blocks in time were used to minimize differences among cows in days of lactation. Ten cows ( 6 with high genetic merit and 4 with average genetic merit) were selected according to DIM (91 to 129) for each block. Five cows within each block (3 from the high and 2 from the average genetic merit group) were assigned randomly to their respective treatment. Diet groups were equalized based on previous milk production, parity of cows (second parity and greater), and genetic group (3 cows with high genetic merit and 2 cows with average genetic merit per diet group within each block). The first block of cows was on trial from February 3, 2002, to April 7, 2002; the second block was on trial from March 9, 2002, to May 11, 2002.

Healthy cows with no metabolic disorders, mastitis, or udder conformation limitations were selected for this study. Management and care for cows in this experiment followed all guidelines recommended by FASS (1999). In addition, a protocol for the trial was filed with and approved by the Iowa State University (ISU) Animal Care and Use committee. A veterinarian from the Veterinary and Diagnostic Production Animal Medicine unit of the ISU College of Veterinary Medicine removed 1 cow from the trial during the last 2 wk of the second period after clinical examination. The cause of removal, chronic endometritis, was determined to not be diet related. Removal date, BW, BCS, and feed refusals were recorded when this cow was removed from the study. Data from this animal were excluded from statistical analysis.

Cows were housed in a free-stall barn bedded with sand and were trained to use individual Calan gate feeders (American Calan, Northwood, $\mathrm{NH}$ ) before the start of the trial. Daily milk production was recorded. Health and physical characteristics measured included $\mathrm{BW}$, body temperature, pulse rate, respiration rate, and BCS. These measurements were collected on consecutive Fridays before and during the trial; measurements collected before the start of the trial were used to establish baseline values. Cows were monitored regularly for mastitis and other abnormal health conditions. All health treatments and abnormal health observations were recorded. Routine treatments including vaccinations required by standard operating procedures at the farm were used. Posilac (bST) was not used in this study.

\section{Clinical Chemistry and Hematology Assays}

Blood samples were collected $7 \mathrm{~d}$ before the start of the trial and at the end of each experimental period (d 28 and 63, respectively). Pretrial samples were collected to establish baseline values. Serum and plasma samples were submitted for clinical chemistry profile and hematological analyses (ISU Veterinary Medicine Clinical Pathology Laboratory, Ames) to assess the health status of the cows during the experiment. Milk samples were collected on consecutive Fridays before and during the trial. Milk samples collected twice daily during each milking period were composited into a single daily sample per cow for analyses. These daily milk samples were submitted to Dairy Lab Services (Dubuque, IA) for compositional analysis (fat, protein, solids, lactose, SCC, and MUN) using infrared procedures (Foss North America, Eden Prairie, MN). Fat-corrected milk (3.5\%) was calculated according to the Gaines formula with adjustments as described by Stoddard (1980); ECM was calculated using the formula described by Bernard (1997); SCM was calculated according to Tyrrell and Reid (1965).

\section{Statistical Analysis}

Results of nutrient analyses for all dietary ingredients, totally mixed diets, and refusals, along with pre- 
Table 2. Nutrient composition of maize grain, harvested whole plant maize fresh forage and fermented forage $^{1}$

\begin{tabular}{|c|c|c|c|c|c|c|}
\hline \multirow[b]{2}{*}{ Item } & \multicolumn{2}{|c|}{ Maize grain } & \multicolumn{2}{|c|}{ Fresh maize forage } & \multicolumn{2}{|c|}{ Fermented maize forage } \\
\hline & TC1507 & Control & TC1507 & Control & TC1507 & Control \\
\hline Particle size, mm & - & - & 11.2 & 10.9 & 9.4 & 9.2 \\
\hline \multicolumn{7}{|c|}{ Nutrient analysis of maize grain, harvested whole plant maize forage, and silage } \\
\hline $\mathrm{pH}$ & - & - & - & - & 3.79 & 3.89 \\
\hline $\mathrm{DM}, \mathrm{g} / \mathrm{kg}$ & 862.7 & 857.7 & 375.8 & 420.2 & 422.4 & 450.8 \\
\hline $\mathrm{CP}$ & 79.7 & 73.6 & 80.6 & 75.0 & 88.1 & 86.4 \\
\hline Acid detergent insoluble CP & - & - & - & - & 7.1 & 8.2 \\
\hline Crude fat & 44.9 & 41.7 & 29.4 & 30.4 & 31.7 & 31.7 \\
\hline $\mathrm{ADF}$ & 42.6 & 39.4 & 258.1 & 264.7 & 277.7 & 294.4 \\
\hline NDF & 90.3 & 80.8 & 461.4 & 380.4 & 439.5 & 452.5 \\
\hline Calcium & 0.2 & 0.2 & 3.0 & 2.5 & 2.5 & 2.7 \\
\hline Phosphorus & 3.1 & 3.1 & 1.7 & 1.9 & 2.2 & 2.2 \\
\hline Magnesium & 1.4 & 1.4 & 3.2 & 2.8 & 2.2 & 2.4 \\
\hline Potassium & 4.4 & 4.1 & 3.4 & 4.4 & 8.2 & 8.1 \\
\hline Lignin & - & - & 53.5 & 33.6 & 33.4 & 36.6 \\
\hline Starch & - & - & 289.3 & 335.1 & 261.8 & 265.1 \\
\hline Ash & - & - & 32.5 & 36.5 & 48.0 & 50.8 \\
\hline Protein solubility, $\%$ of CP & - & - & - & - & 43.87 & 41.70 \\
\hline
\end{tabular}

${ }^{1} \mathrm{TC} 1507$ = maize plants containing the cry $1 \mathrm{~F}$ gene; Control = maize plants isogenic to $\mathrm{TC} 1507$ but not containing the cry $1 \mathrm{~F}$ gene.

trial health and physical measures, milk production and components, and blood chemistry and hematology values, were summarized using PROC MEANS of SAS (version 8.2; SAS Institute Inc., Cary, NC). Cow performance, milk production and composition, and blood chemistry data were analyzed as a 2-period cross-over design using PROC MIXED of SAS. The model's fixed effects consisted of dietary treatment, genetic group, treatment $\times$ genetic group, sequence of treatment, and treatment $\times$ sequence; cow (genetic group block sequence) and block were treated as random effects. Planned comparisons were by Fisher's Protected Least Significant Difference; differences between treatment means were considered significant at $P<0.05$.

\section{RESULTS AND DISCUSSION}

\section{Maize Grain and Silage Characterization}

Nutrient composition and fermentation analysis (Table 2 and Table 3, respectively) revealed that maize grain and silage components of TC1507 and control were similar. The slightly greater DM content of maize silage from the control compared with the TC1507 maize ( 450.8 vs. $422.4 \mathrm{~g} / \mathrm{kg}$ of DM) parallels the difference in DM at harvest ( 420.2 vs. $375.8 \mathrm{~g} / \mathrm{kg}$ of DM) and presumably reflects greater European corn borer infestation of the control maize. Mycotoxin analyses revealed a small amount of vomitoxin $(0.7$ to $1 \mathrm{mg} / \mathrm{kg})$ and fumonisin ( $3 \mathrm{mg} / \mathrm{kg}$, maize grain only) present in both TC1507 and control silage and grain. Concentra- tions in grain and silage were below the Food and Drug Administration action levels of 5 and $30 \mathrm{mg} / \mathrm{kg}$, respectively, for dairy cows (FDA 2000). Presence of the expressed Cry1F protein was confirmed in TC1507 maize grain and maize silage. Concentrations of Cry1F protein in the control maize grain or silage for both blocks of cows during both feeding periods were below the level of detection. The absence of Cry1F protein in control grain and silage reflects adequate isolation of crops in the field (separation of $201 \mathrm{~m}$ ) as well as proper care during harvest and storage to avoid cross-contamination.

\section{Diet and Refusal Composition}

Results of nutrient analyses of diets and refusals from each diet are shown in Table 4. Diets were similar in

Table 3. Fermentation products of whole plant maize fermented forage $^{1}$

\begin{tabular}{lcc}
\hline & \multicolumn{2}{c}{ Fermented maize forage } \\
\cline { 2 - 3 } Item & TC1507 & Control \\
\cline { 2 - 3 } Ammonia nitrogen & 7.3 & \\
Lactic acid & 37.5 & 6.7 \\
Acetic acid & 12.4 & 31.7 \\
Propionic acid & 0.0 & 14.6 \\
Butyric acid & 0.0 & 2.1 \\
Isobutyric acid & 0.0 & 0.0 \\
Ethanol & 0.9 & 0.0 \\
\hline
\end{tabular}

${ }^{1} \mathrm{TC} 1507=$ maize plants containing the cry $1 \mathrm{~F}$ gene , Control $=$ maize plants isogenic to TC1507 but not containing the cry $1 \mathrm{~F}$ gene. 
Table 4. Analyzed nutrient compositions of diets formulated with whole plant maize silage plus maize grain from TC1507 or control plants, ${ }^{1}$ and diet refusals

\begin{tabular}{lrrrrr}
\hline & \multicolumn{2}{c}{ Diet } & & \multicolumn{2}{c}{ Diet refusals } \\
\cline { 2 - 3 } \cline { 6 - 6 } Item & TC1507 & Control & & TC1507 & Control \\
\hline DM, g/kg & 603.2 & 633.2 & & 571.7 & 609.3 \\
\cline { 2 - 3 } \cline { 5 - 6 } & & & & & \\
CP & 164.5 & 164.2 & & 157.3 & 143.6 \\
Crude fat & 48.0 & 46.7 & & 50.4 & 42.6 \\
ADF & 234.1 & 227.2 & & 297.8 & 330.8 \\
NDF & 322.4 & 331.6 & & 404.1 & 458.8 \\
Calcium & 11.2 & 11.6 & & 10.6 & 8.9 \\
Phosphorus & 4.4 & 4.6 & & 4.3 & 3.7 \\
Magnesium & 3.8 & 3.8 & & 3.8 & 3.4 \\
Potassium & 15.6 & 12.1 & & 13.8 & 14.3 \\
\hline
\end{tabular}

${ }^{1} \mathrm{TC} 1507$ = maize plants containing the cry $1 \mathrm{~F}$ gene $;$ Control $=$ maize plants isogenic to TC1507 but not containing the cry $1 \mathrm{~F}$ gene. nutrient composition. Fiber analyses of diet refusals indicated that some preferential sorting occurred; this was not considered to be related to treatment because sorting occurred with cows fed both diets.

\section{Lactation Performance}

Results of animal measurements and milk production are presented in Table 5. Cows fed the treatment diets were similar in all measures demonstrating that diet did not affect BW, BCS, temperature, pulse rate, or respiration rate. This is similar to results of previous trials in which no differences in BCS were detected when dairy cows were fed either genetically enhanced maize silage (Grant et al., 2003; Ipharraguerre et al., 2003) or genetically modified whole cottonseed (Castillo et al., 2001). Effects of feeding genetically modified feedstuffs on pulse and respiration rate of lactating dairy cows have not been reported previously. Cows fed the treatment diets did not differ in DMI, daily milk produc-

Table 5. Physical measures, milk production and production efficiency, and milk components of cows fed diets containing maize silage plus maize grain from TC1507 or control plants ${ }^{1,2}$

\begin{tabular}{|c|c|c|c|c|}
\hline \multirow[b]{2}{*}{ Item } & \multirow[b]{2}{*}{ Pretrial } & \multicolumn{2}{|c|}{ Diet } & \multirow[b]{2}{*}{ SEM } \\
\hline & & TC1507 & Control & \\
\hline \multicolumn{5}{|l|}{ Physical measures } \\
\hline BW, kg & 638.3 & 659.2 & 657.4 & 13.1 \\
\hline $\mathrm{BCS}$ & 3.13 & 3.06 & 3.06 & 0.08 \\
\hline Body temperature, ${ }^{\circ} \mathrm{C}$ & 38.7 & 38.6 & 38.6 & 0.1 \\
\hline Pulse, beats per minute & 66.3 & 69.2 & 68.9 & 0.8 \\
\hline Respiration, breaths per minute & 31.1 & 32.7 & 33.4 & 3.5 \\
\hline \multicolumn{5}{|l|}{ Milk production, $\mathrm{kg} / \mathrm{d}$} \\
\hline DMI, kg/d & - & 27.1 & 27.9 & 0.8 \\
\hline Daily milk & 39.0 & 38.9 & 38.6 & 1.4 \\
\hline FCM & 40.2 & 39.3 & 39.6 & 1.4 \\
\hline ECM & 39.2 & 38.6 & 38.8 & 1.3 \\
\hline SCM & 37.0 & 36.4 & 36.8 & 1.2 \\
\hline \multicolumn{5}{|c|}{ Production efficiency, $\mathrm{kg}$ of milk/ $\mathrm{kg}$ of feed } \\
\hline Milk efficiency & - & 1.44 & 1.40 & 0.05 \\
\hline FCM efficiency ${ }^{3}$ & - & 1.46 & 1.44 & 0.05 \\
\hline \multicolumn{5}{|l|}{ Milk component, $\mathrm{g} / \mathrm{kg}$} \\
\hline Protein & 29.4 & 30.0 & 29.9 & 0.5 \\
\hline Fat $^{4}$ & 37.3 & 36.1 & 36.5 & 1.4 \\
\hline Total solids & 124.5 & 123.6 & 124.9 & 2.1 \\
\hline Other solids & 59.4 & 58.0 & 57.6 & 0.7 \\
\hline Lactose & 49.4 & 48.5 & 48.6 & 0.7 \\
\hline \multicolumn{5}{|l|}{ Milk component yield, $\mathrm{kg} / \mathrm{d}$} \\
\hline Protein $^{3}$ & 1.14 & 1.16 & 1.15 & 0.03 \\
\hline Fat & 1.44 & 1.39 & 1.41 & 0.06 \\
\hline Total solids & 4.83 & 4.79 & 4.82 & 0.21 \\
\hline Other solids & 2.30 & 2.26 & 2.22 & 0.08 \\
\hline Lactose & 1.92 & 1.89 & 1.87 & 0.07 \\
\hline \multicolumn{5}{|l|}{ Other milk components } \\
\hline MUN, mg/dL & 18.6 & 19.1 & 18.7 & 1.2 \\
\hline SCC $, \times 1,000$ & 144.0 & 206.1 & 202.8 & 51.1 \\
\hline
\end{tabular}

${ }^{1} \mathrm{TC} 1507$ = maize plants containing the cry $1 \mathrm{~F}$ gene; Control = maize plants isogenic to TC1507 but not containing the cry $1 \mathrm{~F}$ gene.

${ }^{2}$ Treatment means did not differ $(P<0.05)$.

${ }^{3}$ Genetic group effect $(P<0.05)$.

${ }^{4}$ Treatment $\times$ genetic group interaction $(P<0.05)$. 
Table 6. Chemical profile of blood samples collected from cows fed diets containing maize silage plus maize grain from TC1507 or control plants ${ }^{1,2}$

\begin{tabular}{|c|c|c|c|c|c|}
\hline \multirow[b]{2}{*}{ Item } & \multirow[b]{2}{*}{ Pretrial } & \multicolumn{2}{|c|}{ Diets } & \multirow[b]{2}{*}{ SEM } & \multirow{2}{*}{$\begin{array}{c}\text { Reference } \\
\text { interval }^{3}\end{array}$} \\
\hline & & TC1507 & Control & & \\
\hline Sodium, mEq/L & 140.7 & 141.8 & 141.2 & 0.6 & $132.0-152.0$ \\
\hline Potassium, mEq/L & 4.55 & 4.71 & 4.55 & 0.13 & $3.9-5.8$ \\
\hline Chloride, mEq/L & 99.8 & 99.8 & 99.4 & 1.0 & $100.0-115.0$ \\
\hline Calcium, mg/dL & 9.48 & 9.32 & 9.34 & 0.16 & $8.0-11.4$ \\
\hline Phosphorus, mg/dL & 5.48 & 7.39 & 7.22 & 0.35 & $5.6-8.0$ \\
\hline Magnesium, mEq/L & 2.25 & 2.33 & 2.39 & 0.06 & $1.50-2.90$ \\
\hline Total carbon dioxide, $\mathrm{mEq} / \mathrm{L}$ & 27.8 & 25.5 & 25.4 & 0.5 & $21.0-31.0$ \\
\hline BUN, mg/dL & 20.6 & 23.2 & 20.5 & 2.1 & $10-25$ \\
\hline Creatinine, mg/dL & 0.76 & 0.95 & 0.86 & 0.10 & $0.1-1.8$ \\
\hline Glucose, mg/dL & 64.8 & 62.5 & 63.0 & 1.0 & $40.0-100.0$ \\
\hline Total protein, g/dL & 8.24 & 7.82 & 7.80 & 0.18 & $6.7-7.5$ \\
\hline Albumin, g/dL & 3.76 & 3.55 & 3.54 & 0.06 & $2.5-3.8$ \\
\hline Aspartate aminotransferase, IU/L & 94.8 & 100.4 & 95.3 & 5.4 & $55.0-125.0$ \\
\hline Creatinine kinase, IU/L & 235.1 & 212.8 & 203.0 & 29.5 & $1.0-350.0$ \\
\hline Alkaline phosphatase, IU/L & 44.6 & 41.7 & 42.3 & 2.9 & $25.0-250.0$ \\
\hline Gamma glutamyltransferase, IU/L & 32.5 & 27.8 & 28.2 & 1.9 & $1-50$ \\
\hline Total bilirubin, mg/dL & 0.17 & 0.19 & 0.17 & 0.03 & $0.10-1.60$ \\
\hline Hemolytic indices, mg/dL & 23.6 & 61.4 & 40.3 & 17.0 & $0-50$ \\
\hline Lipemic indices, mg/dL & 2.80 & 4.79 & 5.01 & 1.63 & $0-50$ \\
\hline Icteric indices, mg/dL & 1.05 & 0.44 & 0.40 & 0.12 & $0-2$ \\
\hline Anion gap, mEq/L & 17.8 & 21.4 & 20.9 & 0.5 & $\mathrm{NA}^{4}$ \\
\hline
\end{tabular}

${ }^{1} \mathrm{TC} 1507$ = maize plants containing the cry $1 \mathrm{~F}$ gene; Control = maize plants isogenic to TC1507 but not containing the cry $1 \mathrm{~F}$ gene.

${ }^{2}$ Treatment means did not differ $(P<0.05)$.

${ }^{3}$ Reference intervals established at ISU Veterinary Medicine Clinical Pathology Laboratory, Ames, IA.

${ }^{4} \mathrm{NA}=$ not available.

tion, or efficiency of production of FCM. Similarly, lactation performance of dairy cows was not altered by feeding Bt maize and silage (Folmer et al., 2002) or genetically modified whole cottonseed (Castillo et al., 2001). Dry matter intakes were high, reflecting the time of year that the trial was conducted (late winter through early spring) when requirements for $\mathrm{NE}_{\mathrm{M}}$ are higher.

\section{Milk Composition}

Milk nutrient composition (Table 5) was similar between the 2 dietary treatment groups for all components measured. As expected, cows with high genetic merit for protein produced more milk protein per day than cows with average genetic merit (1.16 vs. $1.15 \mathrm{~kg} /$ d). A dietary treatment by genetic group interaction $(P$ $<0.05$ ) was observed for fat percentage in milk due to a greater difference between genetic groups when fed the control diet ( 38.2 and $34.8 \mathrm{~g} / \mathrm{kg}$ for high and average groups, respectively) than when fed the TC1507 diet (35.8 and $36.4 \mathrm{~g} / \mathrm{kg}$ for high and average groups, respectively). Within genetic groups, values between cows fed TC1507 and control were not significantly different. When fat percentage was averaged across genetic groups, the difference in fat content associated with $\operatorname{diet}(36.1 \mathrm{~g} / \mathrm{kg}$ for cows fed the TC1507 diet vs. $36.5 \mathrm{~g} /$ $\mathrm{kg}$ for cows fed the control diet) was also not significant.
Dietary treatment did not affect protein, total solids, other solids, lactose, or MUN concentrations or SCC. Donkin et al. (2003) similarly observed no change in milk composition when lactating cows were fed Bt (MON810)/glyphosate-tolerant (GA21) maize hybrids. Milk urea nitrogen values, although slightly above the recommended herd average range of 12 to $18 \mathrm{mg} / \mathrm{dL}$ (Drudik et al., 2007), may be typical for this herd as indicated by the high values during the preliminary period.

\section{Blood Chemistry and Hematology}

Results of blood chemistry and hematological analyses are presented in Tables 6 and 7, respectively. No significant treatment effect was observed for any of these traits. Values for most measures fell within the reference intervals for lactating dairy cows established by the ISU Veterinary Medicine Clinical Pathology Laboratory. Chloride values of pretrial, TC1507, and control samples and phosphorus values pretrial all fell below the lower limit of the reference interval. Total protein, mean corpuscular hemoglobin concentration, red cell distribution width, plasma protein, and fibrinogen values for cows fed TC1507 or control diets were above the upper limit of the reference intervals. However, pretrial values for those measures were also above the 
Table 7. Hematological profile of blood samples collected from cows fed diets containing maize silage plus maize grain from TC1507 or control plants ${ }^{1,2}$

\begin{tabular}{|c|c|c|c|c|c|}
\hline \multirow[b]{2}{*}{ Item } & \multirow[b]{2}{*}{ Pretrial } & \multicolumn{2}{|c|}{ Diet } & \multirow[b]{2}{*}{ SEM } & \multirow{2}{*}{$\begin{array}{l}\text { Reference } \\
\text { interval }^{3}\end{array}$} \\
\hline & & TC1507 & Control & & \\
\hline White blood cells, $\times 10^{3} / \mu \mathrm{L}$ & 8.48 & 8.29 & 8.05 & 0.83 & $4.0-12.0$ \\
\hline Red blood cells, $\times 10^{6} / \mu \mathrm{L}$ & 6.15 & 6.35 & 6.29 & 0.12 & $5.0-10.0$ \\
\hline Hemoglobin, g/dL & 10.2 & 10.3 & 10.3 & 0.2 & $8.0-15.0$ \\
\hline Hematocrit, $\%$ & 27.7 & 28.0 & 27.8 & 0.5 & $24.0-46.0$ \\
\hline Mean corpuscular volume, fL & 45.1 & 44.2 & 44.2 & 0.5 & $40.0-60.0$ \\
\hline Mean corpuscular hemoglobin, pg & 16.7 & 16.2 & 16.3 & 0.2 & $11.0-17.0$ \\
\hline $\begin{array}{l}\text { Mean corpuscular hemoglobin } \\
\text { concentration, g/dL }\end{array}$ & 36.9 & 36.7 & 36.9 & 0.1 & $30.0-36.0$ \\
\hline Automated platelet count, $\times 10^{3} / \mu \mathrm{L}$ & 447.4 & 433.0 & 467.1 & 27.4 & $100-800$ \\
\hline Neutrophils, $\times 10^{3} / \mu \mathrm{L}$ & 3.35 & 3.36 & 3.03 & 0.25 & $0.6-4.0$ \\
\hline $\mathrm{AB}$ BAND,$\times 10^{3} / \mu \mathrm{L}$ & 0.008 & 0.003 & 0.005 & 0.006 & $0-0.12$ \\
\hline Lymphocytes, $\times 10^{3} / \mu \mathrm{L}$ & 4.39 & 4.28 & 4.50 & 0.66 & $2.5-7.5$ \\
\hline Monocytes, $\times 10^{3} / \mu \mathrm{L}$ & 0.46 & 0.32 & 0.24 & 0.05 & $0.1-0.9$ \\
\hline Eosinophils, $\times 10^{3} / \mu \mathrm{L}$ & 0.22 & 0.28 & 0.23 & 0.06 & $0.0-2.4$ \\
\hline Basophils, $\times 10^{3} / \mu \mathrm{L}$ & 0.05 & 0.05 & 0.04 & 0.02 & $0.0-0.2$ \\
\hline Red cell distribution width, \% & 20.3 & 20.0 & 20.0 & 0.3 & $8.0-15.0$ \\
\hline Mean platelet volume, fL & 5.15 & 5.28 & 5.27 & 0.17 & $0.0-99.9$ \\
\hline Nucleated red blood cells $/ 100$ cells & 0.00 & 0.00 & 0.05 & 0.04 & $\mathrm{NA}^{4}$ \\
\hline Plasma protein, g/dL & 8.26 & 8.11 & 8.07 & 0.16 & $6.9-7.7$ \\
\hline Fibrinogen, mg/dL & 590.0 & 550.0 & 523.7 & 92.2 & $100-500$ \\
\hline
\end{tabular}

${ }^{1} \mathrm{TC} 1507$ = maize plants containing the $c r y 1 \mathrm{~F}$ gene; Control $=$ maize plants isogenic to $\mathrm{TC} 1507$ but not containing the cry $1 \mathrm{~F}$ gene.

${ }^{2}$ Treatment means did not differ $(P<0.05)$.

${ }^{3}$ Reference intervals established at ISU Veterinary Medicine Clinical Pathology Laboratory, Ames, IA.

${ }^{4} \mathrm{NA}=$ not available.

upper limits and values did not differ $(P<0.05)$ between the TC1507 and control groups. Hemolytic indices from the TC1507 treatment were above the upper limit; however, values did not differ $(P<0.05)$ between dietary treatments; the greater values likely were related to differences between personnel that drew the blood samples. Blood urea nitrogen concentrations were reanalyzed using only period 1 values due to an observed effect $(P<0.05)$ of feeding sequence in the initial analysis that indicated the possibility of a carryover effect from period 1 to period 2. Reanalysis using period 1 data detected no significant effect of dietary treatment on BUN. The BUN values were reflected in the MUN values, a correlation that has been well established (Broderick and Clayton, 1997). The greater protein values may have been influenced by the presence of the high milk protein genetic merit group in this herd. Blood chemistry and hematological measurements indicated that feeding TC1507 did not statistically alter $(P<0.05)$ these values. No research data have been published previously evaluating blood chemistries of lactating dairy cows fed genetically enhanced feedstuff.

\section{CONCLUSIONS}

Health and productivity of lactating dairy cows were not different between cows fed TMR containing a new generation $\mathrm{Bt}$ maize silage plus grain and cows fed a control maize silage plus grain. Milk composition, clinical blood chemistries, and hematology indices were not affected by source of maize silage and grain.

\section{REFERENCES}

AOAC. 1995. Official Methods of Analysis. 16th ed. Association of Official Analytical Chemists, Arlington, VA.

ASAE. 2001. S424: Method of determining and expressing particle size of chopped forage materials by sieving. Pages 576-578 in Standards. 47th ed. Am. Soc. Agric. Eng., St. Joseph, MI.

Bernard, J. K. 1997. Milk production and composition responses to the source of protein supplements in diets containing wheat middlings. J. Dairy Sci. 80:938-942.

Broderick, G. A., and M. K. Clayton. 1997. A statistical evaluation of animal and nutritional factors influencing concentrations of milk urea nitrogen. J. Dairy Sci. 80:2964-2971.

Castillo, A. R., M. R. Gallardo, M. Maciel, J. M. Giordano, G. A. Conti, M. C. Gaggiotti, O. Quaino, C. Giani, and G. F. Hartnell. 2001. Effect of feeding dairy cows with cottonseeds containing Bollgard and Roundup Ready genes or control non-transgenic cottonseeds on feed intake, milk yield and milk composition. J. Dairy Sci. 84(Suppl. 1):413. (Abstr.)

Donkin, S. S., J. C. Velez, A. K. Totten, E. P. Stanisiewski, and G. F. Hartnell. 2003. Effects of feeding silage and grain from glyphosate-tolerant or insect-protected corn hybrids on feed intake, ruminal digestion, and milk production in dairy cattle. J. Dairy Sci. 86:1780-1788.

Drudik, D., J. F. Keown, and P. J. Kononoff. 2007. Milk Urea Nitrogen Testing. G1661. University of Nebraska-Lincoln Extension, Lincoln.

Eaton, A. D., L. S. Clesceri, and A. E. Greenberg, ed. 1995. Standard Methods for the Examination of Water and Wastewater. 19th ed. Am. Public Health Assoc., Washington, DC. 
FASS (Federation of Animal Science Societies). 1999. Guide for the Care and Use of Agricultural Animals in Agricultural Research and Teaching. 1st rev. ed. Federation of Animal Science Societies, Savoy, IL.

Faust, M., and L. Miller. 1997. Study finds no Bt in milk. Iowa State University Integrated Crop Management Newsletter IC-478, Special Livestock Edition. Iowa State University, Ames.

Folmer, J. D., R. J. Grant, C. T. Milton, and J. Beck. 2002. Utilization of Bt corn residues by grazing beef steers and Bt corn silage and grain by growing beef cattle and lactating dairy cows. J. Anim. Sci. 80:1352-1361.

Food and Drug Administration. 2000. Action levels for poisonous or deleterious substances in human food and animal feed. http:// vm.cfsan.fda.gov/ lrd/fdaact.html Accessed Oct. 8, 2003.

Goering, H. K., and P. J. Van Soest. 1970. Forage Fiber Analysis. USDA Agricultural Research Service. Handbook number 379. US Department of Agriculture, Washington, DC.

Grant, R. J., K. C. Fanning, D. Kleinschmit, E. P. Stanisiewski, and G. F. Hartnell. 2003. Influence of glyphosate tolerant (event nk603) and corn rootworm protected (event MON863) corn silage and grain on feed consumption and milk production in Holstein cattle. J. Dairy Sci. 86:1707-1715.

International Life Sciences Institute. 2003. Best practices for the conduct of animal studies to evaluate crops genetically modified for input traits. International Life Sciences Institute, Washington, DC.

Ipharraguerre, I. R., R. S. Younker, J. H. Clark, E. P. Stanisiewski, and G. F. Hartnell. 2003. Performance of lactating dairy cows fed corn as whole plant silage and grain produced from a glyphosatetolerant corn (event NK603). J. Dairy Sci. 86:1734-1741.

Krishnamoorthy, U., T. V. Muscato, C. J. Sniffen, and P. J. Van Soest. 1982. Nitrogen fractions in selected feedstuffs. J. Dairy Sci. 65:217-225.

Mueller, J. P., J. T. Green, and W. L. Kjelgaard. 1987. Corn silage harvest techniques, National Corn Handbook, Coop. Ext. Serv., Purdue Univ. W. Lafayette, IN. http://www.ces.purdue.edu/ extmedia/NCH/NCH-49.html Accessed June 8, 2006.

NRC. 2001. Nutrient Requirements of Dairy Cattle. 7th rev. ed. Natl. Acad. Sci., Washington, DC.

Raymond, S. L., T. K. Smith, and H. V. L. N. Swamy. 2003. Effects of feeding a blend of grains naturally contaminated with Fusarium mycotoxins on feed intake, serum chemistry, and hematology of horses, and the efficacy of a polymeric glucomanan mycotoxin adsorbent. J. Anim. Sci. 81:2123-2130.

Roth, G. W., and A. J. Heinrichs. 2001. Agronomy Facts 18: Corn silage production and management. The Pennsylvania State University, University Park. http://www.cropsoil.psu.edu/extension/ facts/agfact18.pdf Accessed June 8, 2006.

Siegfried, V. R., H. Ruckermann, and G. Stumpf. 1984. Method for the determination of organic acids in silage by high performance liquid chromatography. Landwirtsch. Forsch. 37:298-304.

Stoddard, G. E. 1980. How fat-corrected milk originated. Hoard's Dairyman 125:319.

Tyrrell, H. F., and J. T. Reid. 1965. Prediction of the energy value of cow's milk. J. Dairy Sci. 48:1215-1223. 